\title{
Identifying the Drivers of Student Retention: A Service Marketing Approach
}

\author{
Amy Rummel, Ph.D. ${ }^{a^{*}}$, Maeghen L. MacDonald ${ }^{\mathrm{b}}$ \\ a Professor of Marketing, Alfred University. \\ b Penn State University. \\ *Corresponding author's email address: frummel@alfred.edu.
}

\section{A R T I C L E I N F O}

Received: 18-02-2016

Accepted: 11-03-2016

Available online: 13-05-2016

Keywords:

Student retention, higher education, service marketing, Student satisfaction.

JEL Classification: M31, I23

\begin{abstract}
A B S T R A C T
Examination of Higher Education literature concerning student retention reveals a variety of influences from student satisfaction, professors' engagement and/or approachability with students. However, as with most complex issues there appears to be multiple causes for student disengagement. This paper presents a "service marketing" approach to understanding student retention. If a university system is couched in terms of multiple, interactive service encounters, are there interactions which take place on a campus which would lead to a students' satisfaction/dissatisfaction with that University? The results indicate that this is in fact true. While the student-teacher interaction is still critical to retaining students, additional interactions with support staff also emerge as having significant impact on the retention of students. Implications for "customer service" training across all venues within a University are discussed.
\end{abstract}

(C) 2016 The Authors. This is an open access article under the terms of the Creative Commons Attribution License 4.0, which allows use, distribution and reproduction in any medium, provided the original work is properly cited.

DOI: http://dx.doi.org/10.18533/job.v1i4.21

\subsection{Introduction}

In today's economic and social climate higher education institutions are facing increased pressure to raise retention rates while battling a declining initial enrollment. According to the U.S. Department of Education, Center for Educational Statistics, only $50 \%$ of those who enter higher education actually earn a bachelor's degree (Seidman, 2005). Due to this, enrollment management and the retention of students remain a top priority of federal and state government, colleges, universities, and parents of students who are attending college as well as students themselves (Seidman, 2005; St. John, 2000). In order to reverse this trend, higher education administrators are increasing their focus and administrative effort towards understanding why students depart from institutions prematurely and what can be done to reverse these trends (Roberts \& Styron, 2010; Tinto, 1993).

There is no doubt that student satisfaction has a positive impact on, if not highly correlated to student motivation and retention (Elliott and Shin, 2002; Shah, 2009). For many years it was the common belief that teachers in Higher Education were the primary if not the only factor that drove student satisfaction. This assumption has impact on the behaviors of upper administration and resource deployment within Higher Education. The thought process has been, "If we higher high powered researchers or outstanding teachers, students will be retained". The outcome of this mentality has been increased pressure on teacher performance, 
punitive attitude towards educational divisions with low retention rates and/or resource and training deployment away from other University support services. Research in the area of student retention in higher education has so directed in looking only at the impact of teacher performance that other factors which may impact retention has been obscured (McCay \& Estrella, 2008; Pacscarella, 1980). This paper proposes that any University is an aggregate of service encounters, of which only one of these service encounters is the interaction between a teacher and a student. Borrowing previous research from the marketing service literature, this paper proposes that like any consumer interaction with a "service" provider, the level of satisfaction and repeat "purchase" or engagement/loyalty is not determined by a single encounter but by a summation of the total experience (Berry, 2000). By examining all services offered at a University which a student must interact with (student affairs, financial aid, etc.) a better understanding of what influences or drives student satisfaction resulting in higher rates of retention (Sidle \& McReynolds, 2009).

This research breaks down the university as a whole into its service components. Students are then asked a series of questions which evaluate that particular service encounter (e.g. Treated with courtesy, quality of advice). The survey data is then analyzed by regression modelling to determine those significant factors or drivers which are significantly predicting overall satisfaction and a sense of belonging to the University. Results indicate that students' positive affect towards the institution, while highly affected by teacher-student interaction, is also affected by other staff interactions across campus

\section{$2.0 \quad$ Literature review}

\subsection{Importance of retention}

Understanding retention is important for many reasons. For the employed in higher education setting, there is a moral obligation to help students achieve satisfaction in their academic and social lives. There is also a certain level of responsibility to provide an atmosphere that is conducive to each student's ability to build a solid foundation of knowledge and skills in order to enter the world of employment (Pascarella and Terenzini, 2005). While the moral responsibilities linked to student retention are important, the financial impact that is the result of attrition vs. persistence often provides the rationales to understand retention as much as possible. There is an obvious connection between an institution's financial stability and student persistence.

While one approach to improving retention may be to focus on minimizing factors which have a negative impact, it may behoove an institution to, instead, focus their energy on efforts that can have a positive on retention numbers (Sidle \& McReynolds, 2009). To that end, it is important to first understand that positive relationships tend to help students the most and are in fact the strongest indicators of student persistence. (Brooks, 2010; Fike \& Fike, 2008) Many students report that the most important factor that influenced their decision to remain in school was a positive relationship with someone on campus (Roberts \& Styron, 2010). These relationships could be with other students, faculty, coaches, advisors, support staff and so forth. Hence, with the multitude of interactions a student may have on campus, each potentially an important one, retention efforts cannot be narrowly focused on only those relationships formed between the teacher and student. University administration must understand that it is the responsibility of all campus constituents to provide an atmosphere conducive to these relationships forming and growing.

Lau (2003) suggest that hiring the "right" people is the first step towards creating an environment in which these meaningful relationships can be formed, but it may take more than just hiring the right people. Naturally, good customer service requires hiring involved and caring faculty, but customer service is also delivered by all those who have even one interaction with a student (Li and Whalen, 2005). In fact, students have more service interactions outside the classroom than within. Creating a supportive environment to aid in the retention of student is everyone's job. Teachers are only one delivery system (that of knowledge) within entire delivery system

\subsection{Student satisfaction/service quality}

The economic climate plus the mindset of the modern student of being a customer rather than participant in their higher education, creates a high priority to ensure the student is satisfied both in and out of the classroom. Students spend an average of 15 hours per week in the classroom, leaving 153 hours left to choose to do whatever they desire. There is a debate of focusing on assessing teaching and learning and assessing the total student experience (Aldridge and Rowley, 1998).

Much of the earlier research on student retention focused on singular "service encounters" such as first year experiences (Madgett and Belanger, 2008), residence life (Luna, 1998; Li and Whalen, 2005) and specialized 
educational programs aimed at underperforming students (Hoyt, 1999). The driving force behind much of this research was to understand why students were leaving universities and how it could be fixed. While this was extremely helpful to the academic community, it was a bit like plugging one leak where another would appear. This also lead to unrealistic expectations. The thought process was if "we" can develop an outstanding first year experience for students and engage them, our retention rates should increase. Sadly, most institutions have experienced that this singular approach is too simple to a multifaceted problem.

However, during the last decade, research has focused more towards the total student experience (Quinn, Lemay, Laren and Johnson, 2009; Roberts \& Styron, 2010). With this trend of thinking, it is imperative for universities to understand and deliver what is important to students (Elliott and Shin, 2002). In fact, many universities are engaging students into this process (McClenney and Waiwaiole, 2005). Like many service and product organizations, conducting market research to determine how to enhance a "customer's experience" has been embraced by many Universities as a way to understand all factors driving retention. More and more institutions are adapting a services marketing model to understand and affect retention rates (Henning-Thurau, 2001; Nadiri, Kandampully and Hussain, 2009). With a strong level of service quality, customer (student) satisfaction, enhanced return rates (retention), and high recommendations can be achieved (Brown and Mazzarol, 2008; Nadiri and Hussain, 2005).

\subsection{Importance of service encounters in higher education}

Much of the literature in the Berry (2000) identified that consumers direct (versus indirect/hearsay) experiences with service organizations have significant impact on the service evaluation and therefore loyalty to that service. This places high importance on the customers' interaction with each "service encounter". In an educational setting, these interactions take place not only in the classroom between teacher and student but with the various services across campus. Furthermore, it has also been established that satisfaction with service executions aid in the prediction of repurchases intentions (Hume, 2011). The implication for universities is that with each service encounter, students are continually re-evaluating their "repurchase intention" of that university. By ensuring that all aspects of campus services aid students' campus experiences, a positive evaluation will result, supporting higher retention rates.

One of the critical assumptions that is made in this paper as well as others research is that the University can only affect retention rates as they relate to student satisfaction. In other words, students who disengage from a University due to financial difficulties, location issues, and family issues, for instance, cannot be "controlled" or affected by any programmatic efforts on the part of the University. These students will/must leave. By eliminating this population of students who will leave because of "uncontrollable" factors on the part of the University, delivery of critical services can be focused.

A service marketing approach to student retention assumes that student satisfaction is the sum of all of its controllable experiences (Alves and Raposo, 2009; Kwek, Lau and Tan, 2010). Given this simplistic model, there are two key factors to identify. The first being those key service encounters which contribute to the overall evaluation of the institution. Secondly, it is also assumed that not all service encounters carry the same importance. While a student can have a bad experience with the Office of Financial Aid, that in and of itself will not result in a poor evaluation of or affect for the University. A student might be more affected by a positive interaction with a teacher or a registrar and totally discount a previously negative interaction.

In summary this paper proposes that retention is driven by student satisfaction which in turn is driven by those important service interactions. Specifically this research focuses on understanding the relationship between service quality/evaluation and student satisfaction. It is proposed that student satisfaction and hence retention is affected by a multitude of interactions across a university campus. As a student interfaces with financial aid, the registrar, student services, professors, and so forth, $\mathrm{s} / \mathrm{he}$ are making evaluations based on these interactions which will affect his/her overall evaluation of the University.

\subsection{Methodology}

A random sample of students across all academic standings from a small private liberal arts university completed a questionnaire to assess their satisfaction with various service areas across campus, their overall satisfaction with their specific college (Liberal arts, Business, Engineering, Art and Design) and their overall satisfaction with the University. This survey was based on previous literature examining service quality and impact (eg. Alves and Raposo, 2009; Kwek, Lau and Tan, 2010). To measure service quality encounters within the academic setting, the questionnaire was segmented into assessment areas of: courtesy and respect, trust, service quality and overall satisfaction with the service area. Overall satisfaction was measured by four 
questions: Overall satisfaction, exceeds expectations, I am loyal to this college and I have a sense of belonging. These questions were 5 point Likert scales asking respondents to strongly disagree to strongly agree with each statement (i.e., I am loyal to this college). These four measures were used as the dependent variables in separate regression modelling.

In order to identify which units on campus students had experience with, students self-identified two service areas to evaluated (open ended question) along with the number of times $\mathrm{s} / \mathrm{he}$ interacted with that department. Each unit was given a specific code when entered into Spssx. In other words, any student who identified that they interacted with the financial aid department 10 times, financial aid was always coded as " 1 " and the number 10 was entered into the data base indicating that there were 10 encounters with unit " 1 " or financial aid. This additional data was used to identify for the University if there were problem units on campus as well as to control for possible effects of the frequency of interactions with a particular unit. In other words, it was important to know if increased interaction with a unit, increased liking or satisfaction. The analysis showed, that in fact, is true. This result will be discussed in the results section.

\subsection{Results}

Four hundred and eighty three students comprised the respondent base. Two hundred sixty three were male and 220 were female with an equal representation across all class standing (first year students to seniors).

Three fundamental analyses were conducted to determine first, if there is indeed a relationship between the numbers of visits to a respondent's satisfaction level, secondly to assess the extent of correlation between measures of student satisfaction (dependent variables) and then to determine those factors (independent variables) which impacted student satisfaction.

\subsection{Service interactions impact of university evaluations}

Based on the question "I am satisfied with this University overall" and the number of visits to a service area, there was a significant relationship $(\mathrm{p}=.028, \mathrm{n}=483)$. This relationship suggests that the more an individual interacted with a service area, the higher the impact on their positive or negative evaluation of the University. This implies that all units on a campus have potential impact on a student's satisfaction. This is possibly why there is an accepted belief that professors/teachers are responsible for student satisfaction given that students have repeated interaction in and out of the classroom with their instructors. This result, however, expands this belief to encompass any service unit which the student has frequent interaction.

\subsection{Multi-co-linearity of dependent variables}

The extant literature on student retention has used multiple measures of student satisfaction or commitment to a University. For this research students were asked a series of questions that served as the dependent measures within the survey. These questions served as surrogate measures of student satisfaction. They were 1)"I feel a strong sense of belonging to this college" 2) "My experiences at this college have exceed my experience" 3)I am satisfied with this college overall" and finally 4) "I am very loyal to this college". A test of correlation was performed to determine how interrelated all of these dependent variables were. As expected there was a high correlation between all four. This implies that these questions were all "testing" aspects of the same type of construct, a sense of loyalty/satisfaction with the University.

\subsection{Drivers of student satisfaction}

To further explore the data, regression analyses were conducted using each of the overall ratings provided by the respondents. While there was a high correlation (significant) between the 4 dependent variables, the correlation was not perfect. By further exploring the data set, it could be determined if there were any nuances within the data to add to our better understanding of student happiness, satisfaction and therefore and in retention efforts. Results are displayed in Tables 1 through 4

\begin{tabular}{lrr}
\hline \multicolumn{3}{c}{ Table 1: Satisfaction drivers: I feel a strong sense of belonging to this College } \\
\hline Variable & t value & Sig. \\
\hline The college is trustworthy because it is concerned with the students best interests & 5.35 & .000 \\
Professors are ready to answer my questions & 2.36 & .018 \\
Staff met my needs & 2.08 & .038 \\
I am able to get help when I need it & 2.04 & .042 \\
\hline
\end{tabular}


As it can be seen in Table 1, there are four major factors which drive a student's sense of belonging to a college and therefore (based on previous retention literature) drive student retention. These are: "trust that a college is truly concerned with students best interests", "professors willingness to answer questions", "campus staff able to meet student needs" and "ability to get help". These results indicate that a sense of belonging is driven by a sense of trust and honesty. One interpretation is that students emotionally invest in a college or university when the university community can fulfill their needs. Professors, as well as staff, should be able to answer questions concerning their student life on campus (in and out of the classroom). Furthermore, it is important that a student has a sense from the campus community that they are supported and trusted. Tables 2 through 4 provide additional support to these interpretations.

Table 2: Satisfaction Driver: My experience at this college have exceeded my expectations Variable

The college has the ability to provide for my needs $\mathrm{t}$ value Sig

Professors are enthusiastic or eager to solve my problems

$6.10 \quad .000$

$2.8 \quad .000$

The college is trustworthy because it is concerned with the

2.68

.008 students interests

Staff fully meet my needs

2.35

.019

I am treated with courtesy

I am treated with respect

2.4

.017

The colleges procedures are reasonable

1.96

.048

One of the interesting drivers to emerge in this analysis is "college procedures are reasonable". This implies that Universities need to examine their procedures on campus as it relates to student life. Can systems be streamlined so that students are able to efficiently drop and add classes, meet their financial obligations, complete their education in a timely manner and so forth? Consumer industries such as retailing build their customer satisfaction programs on the ease of access. Can Universities do the same so that students feel that they are being treated as valued members of a community and what they are being asked to do (obtain a signature) is perceived to be valid and reasonable?

Table 3: Satisfaction Driver: I am satisfied with this college overal

The college has the ability to provide for my needs

Professors are ready to answer my questions

Professors are enthusiastic to resolve my problems

The college is trustworthy because it is concerned with the students interests

Staff meets my needs

Professors seem knowledgeable about all of my questions and concerns t value

3.5

3.01

3.12

2.06

2.04
.000

.001

.003

.002

.04

.04

Table 4: Satisfaction Driver: I feel a strong sense of belonging to this college

Professors are ready to answer my questions

The college is trustworthy because it is concerned with the students

These responses in Tables 3 and 4 identify those attributes which drive a student's satisfaction with a specific academic unit. Not surprisingly, professors' actions play a significant role in the satisfaction with students' connection with the college and therefore the University. However, it should be noted that "staff" within each unit have a significant impact on satisfaction and therefore retention. This data would suggest that professors and staff within a unit are both critical to potential retention efforts

\subsection{Conclusion and recommendations}

This paper examines the validity of applying the concepts of service marketing and customer service to the area of student retention. The results indicate that in addition to in-classroom interaction with professors, other units on campus have significant impact on students' sense of belonging to a University. For instance, staff competency ("staff is able to answer my questions") is critical to student satisfaction. This makes sense. In most 
cases students seek help from a variety of support services when they don't have the answer. Navigating the financial aid arena, accessing academic or personal support from student services, adding and dropping classes are just a few instances where students' life on campus can be deeply affected. These types of occurrences place a student in an anxious and/or frustrating situation. The ability for them to be able to interact with personnel who treat them with respect, are courteous, show true concern for the students' well-being and have the answers would have significant impact on their satisfaction as these results indicate. Sending students to a variety of campus units at various locations due to a lack of staff knowledge is detrimental.

Based on this research, approaching student retention in a holistic manner suggests that the focus of universities should be on adequate training for all support staff that have interactions with their student population. This training is not just on the knowledge of the job, but also on the interactions with their "consumers", the students. Students, just like any other type of consumer, has the ability to "take their business elsewhere"- and in many instances, they are. Focusing away from a single component of interaction (teachers) and understanding that loyalty to a university or college is the summation of interactions with a multitude of individuals should enhance retentions rates, according to this research study.

\section{References}

Aldridge, S. and Rowley, J. (1998). Measuring customer satisfaction in higher education. Quality Assurance in Education, 6 (4) 197. http://dx.doi.org/10.1108/09684889810242182

Alves, H. and Raposo, M. (2009). The measurement of the construct satisfaction in higher education. The Services Industries Journal, 29 (2), 203-218. http://dx.doi.org/10.1080/02642060802294995

American Association of Community Colleges. (2000). National profile of community colleges: Trends and statistics 3rd edition. Washington, D.C.: Community College Press.

Berry, L.L. (2000) Cultivating service brand equity. Journal of the Academy of Marketing Science, 28(1), 128137. http://dx.doi.org/10.1177/0092070300281012

Brooks, S. E. (2010). The connection between residence life and first-year student retention at the University of Pittsburgh. Journal of College and University Student Housing, 37(1), 12-23.

Brown, R. and Mazzarol, T. (2008). The importance of institutional image to student satisfaction and loyalty within higher education. Higher Education, 58, 81-95. http://dx.doi.org/10.1007/s10734-008-9183-8

Elliott, K. and Shin, D. (2002). Student satisfaction: an alternative approach to assessing this important concept. Journal of Higher Education Policy and Management, 24 (2), 197-209. http://dx.doi.org/10.1080/1360080022000013518

Fike, D. S., Fike, R., (2008). Predictors of first-year student retention in the community college. Community College Review, 36(2), 68-88. http://dx.doi.org/10.1177/0091552108320222

Henning-Thurau, T., Langer, M.F., and Hansen, U. (2001). Modeling and managing student loyalty: An approach based on the concept of relationship quality. Journal of Service Research, 3 (4), 331-344. http://dx.doi.org/10.1177/109467050134006

Hoyt, J. E. (1999). Remedial education and student attrition. Community College Review, 27(2), 1-72. http://dx.doi.org/10.1177/009155219902700203

Hume, M.,(2011) How do we keep them coming: examining museum experiences using a services marketing paradigm. Journal of Nonprofit and Public Sector Marketing, 23:71-94. http://dx.doi.org/10.1080/10495142.2011.548759

Kwek, C.L., Lau, T.C., and Tan, H. P. (2010). Education quality process model and its influence students' perceived service quality. International Journal of Business and Management, 5(8), 154-165.

Lau, L. K. (2003). Institutional factors affecting student retention. Education, 124(1), 126-136.

Li, Y., Sheely II, M.C., Whalen, D. F. (2005). Contributors to residence hall student retention: Why do students choose to leave or stay? Journal of College and University Student Housing, 33(2), 28-36.

Luna, A. (1998). Measuring both importance and satisfaction to achieve a greater understanding of residence hall life. Journal of College and University Student Housing, 27(1), 25-33.

Madgett, P.J., Belanger, C. H. (2008). First university experience and student retention factors. Canadian Journal of Higher Education, 38(3), 77-96.

McCay, V.C. and Estrella, J. (2008). First generation student success: The role of faculty interaction in service learning courses. Communication Education, 57(3), 356-372. http://dx.doi.org/10.1080/03634520801966123

McClenney, K. M., Waiwaiole, E. N. (2005). Focus on student retention. Community College Journal, 75(6), 36-41.

McClenney, K. M., Waiwaiole, E. N. (2005). Student voices on student retention. Community College Journal, 75(5), 33-36.

Nadiri, H., and Hussain, K. (2005). Perceptions of service quality in North Cyprus hotels. International Journal of Contemporary Hospitality Management. 17 (6), 469-480. http://dx.doi.org/10.1108/09596110510612112 
Nadiri, H., Kandampully, J., Hussain, K. (2009). Students' perception of service quality in higher education. Total Quality Management, 20 (5), 523-535. http://dx.doi.org/10.1080/14783360902863713

National Collegiate Retention and Persistance to Degree Rates. (2010). Retrieved from: www.act.org/research/policymakers/pdf/retain_2010.pdf.

Quinn, A., Lemay, G., Larsen, P., and Johnson, D. (2009). Service quality in higher education. Total Quality Management, 20 (2), 139-152. http://dx.doi.org/10.1080/14783360802622805

Roberts, J., Styron Jr., R. (2010). Student satisfaction and persistence: Factors vital to student retention. Research in Higher Education Journal, 6, 1-18.

Rochford, R. A., (2004). Improving academic performance and retention among remedial students. Community College Enterprise, 10(2), 23-37.

Scroggin, D., Styron, R. (2006). Factors associated with student withdrawal from community college. Community College Enterprise, 12(1), 111-124.

Seidman, A. (2005a). Introduction. In A. Seidman (Ed.), College student retention (pp. xi-xiv). Westport: Praeger Publishers.

Shah, A. (2009). The impact of quality on satisfaction revenue, and cost as perceived by providers of higher education. Journal of Marketing for Higher Education, 19, 125-141 http://dx.doi.org/10.1080/08841240903451324

Sidle, M. W., McReynolds, J.. (2009). The freshman year experience: Student retention and student success. NASPA Journal, 46(3), 434-446. http://dx.doi.org/10.2202/1949-6605.5019

St. John, E. P., (2000). The impact of student aid on recruitment and retention: What the research indicates. New Directions for Student Services, 89, 61-75. http://dx.doi.org/10.1002/ss.8905

Tinto, V. (1993). Leaving college: Rethinking the causes and cures of student attrition (2nd ed.). Chicago, IL: The University of Chicago Press. 